\title{
$\begin{array}{lllllllll}\text { I } & \mathrm{N} & \mathrm{S} & \mathrm{T} & \mathrm{I} & \mathrm{T} & \mathrm{U} & \mathrm{T} & \mathrm{E}\end{array}$
}

\section{With Less Migration, Natural Increase is Now More Important to State Growth}

\author{
KENNETH M. JOHNSON
}

$\mathrm{D}$ ata released by the U.S. Census Bureau on December 23, 2009, documents the continuing reduced levels of domestic migration (movement from one state to another) in the United States as a result of the economic recession.

For states that gained the most from domestic migration during the mid-decade boom years, the impact of the migration slowdown has been substantial. Florida, long a major recipient of migrants from other states, saw its domestic migration drop from a gain of 263,000 in 2005 to a loss of 31,000 last year (Figure 1). This is the second straight year for domestic out-migration from Florida, and the loss last year is considerably larger than the loss of 9,000 in 2008. Nevada also suffered a domestic migration loss of 4,000 last year after gaining as many as 56,000 domestic migrants as recently as 2005. Arizona's inflow dropped from 124,000 to only 15,000 last year. Even Georgia and North Carolina, which appeared to be weathering the domestic migration downturn, now show sharply reduced levels of domestic migration gain.

Among states that suffered large domestic migration losses during the boom years, the situation is quite different. With

\section{Key Findings}

With migration at record lows, births and deaths fueled most population increase.

- Population gains declined sharply in Florida, Nevada, and Arizona due to reduced migration.

- Population gains increased in Massachusetts and New York due to less outmigration. the exception of Michigan, each of the five states with the great migration losses in 2005 either lost fewer domestic migrants last year or actually gained some. In New York, the domestic migration loss last year was 98,000 compared to a loss of nearly 233,000 in 2005 . Massachusetts enjoyed a modest domestic migration gain of 4,000 last year after losing more than 60,000 domestic migrants as recently as 2005. Ohio and Illinois also experienced less migration loss than they had in 2005.

\section{Natural Increases Now More Important}

With domestic migration at record postwar lows and with immigration also reduced, population growth in the United States depends increasingly on the excess of births over deaths. At the national level, natural increase (the excess of births over deaths) accounted for 67 percent of the total population gain last year. But there are distinct regional- and state-level differences in how much influence natural increase has on population growth. In the Midwest, natural increase accounted for all the population gains last year-offsetting migration losses. In the Northeast, natural increase accounted for most (88 percent) of the population gain, but it only accounted for 51 percent of the growth in the South and 68 percent of the growth in the West.

The heightened influence of natural increase is most evident in the states that enjoyed the largest migration gains during the mid-decade boom. With migration gains sharply lower in these states, continuing growth now depends less on migration and more on natural increase. In Florida, population gains dropped from 404,000 in 2005 to 114,000 last year. In 2005, migration fueled virtually the entire population gain in Florida, with natural increase accounting for only 14 percent of state population increase. Last year,

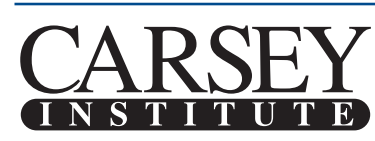

BUILDING KNOWLEDGE FOR FAMilies ANd Communities IN THE 21ST CENTURY
Huddleston Hall, 73 Main Street, Durham, NH 03824

(603) 862-2821 • www.carseyinstitute.unh.edu

This work is supported by the Annie E. Casey Foundation's initiative to strengthen rural families and the W. K. Kellogg Foundation.
UNIVERSITY

of NEW HAMPSHIRE 


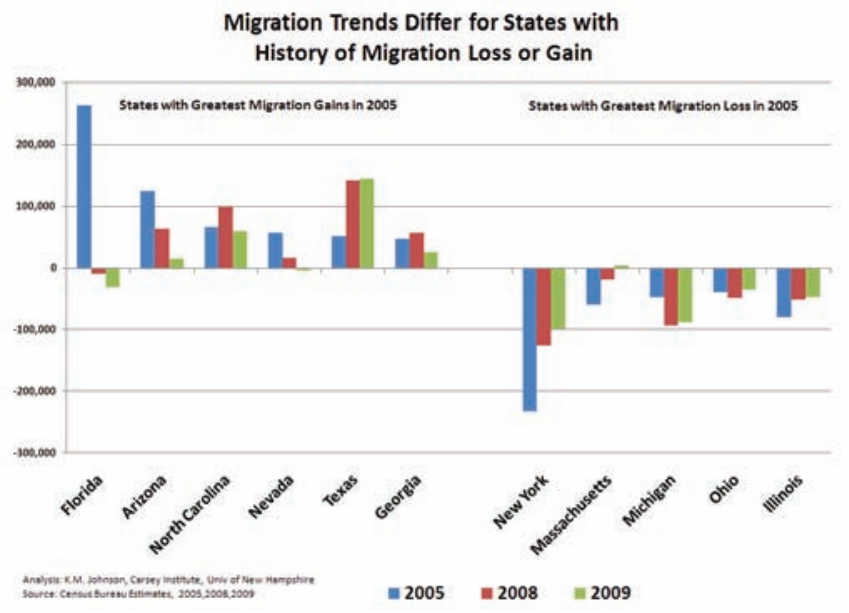

the excess of births over deaths accounted for 51 percent of the population gain (see Figure 2). Similar trends are evident in other fast-growing states. In Arizona, natural increase accounted for 25 percent of the growth during the boom years but 56 percent last year. In Nevada, only 19 percent of the growth during 2005 was from natural increase, but last year, it caused a full 75 percent of the state's population gain. In North Carolina and Georgia, where migration gains diminished less, natural increase still accounted for 40 percent and 58 percent of the population gain last year.

In states that suffered significant domestic migrant loss during the boom-like Massachusetts and New York-the story is quite different. Here natural increase combined with immigration and smaller domestic migration losses has reduced or even reversed population loss. This is a striking contrast to the situation during the migration boom, when natural increase together with immigration had to offset huge domestic migration losses. In 2005, New York's population diminished by 26,000 because it lost 233,000 migrants in exchanges with other states. Even with 99,000 more births than deaths and 109,000 immigrants, New York's domestic migration loss was too great to offset. In contrast, New York grew by 74,000 last year because the domestic migration loss diminished to 95,000, and this was more than offset by a natural increase of 95,000 and 75,000 immigrants. In Massachusetts, the change was even more dramatic. In 2005, the state had a natural increase of 24,000 and an immigration gain of nearly 27,000 , but the state lost 9,000 people because more than 60,000 people left Massachusetts for other states. Last year, Massachusetts actually gained nearly 4,000 domestic migrants, and this combined with a natural increase of 22,000 and an immigration gain of 25,000 produced a population gain for the state of nearly 50,000 .

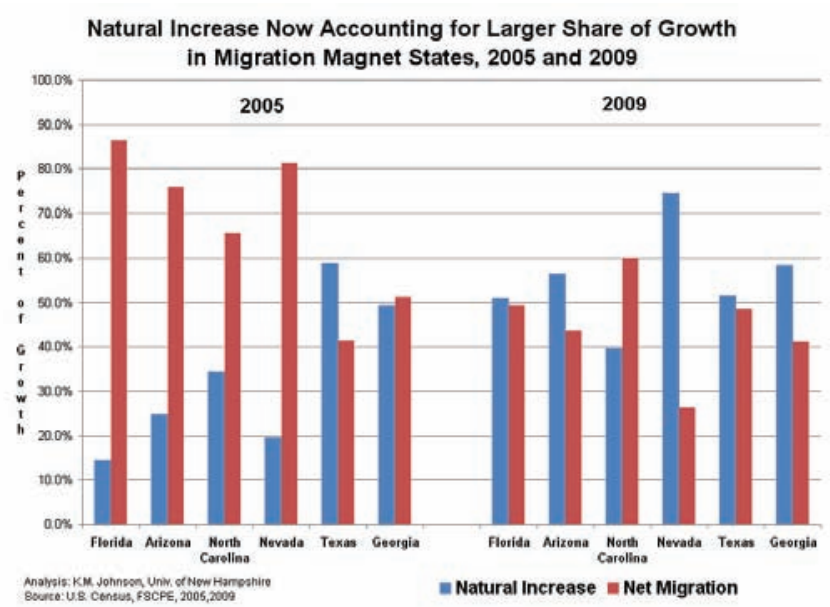

\section{Implications of Demographic Trends}

Changing demographic trends and the growing importance of natural increase in the face of reduced migration has important implications for the reallocation of seats in the U.S. Congress next year. Recent media speculation regarding whether Minnesota will retain its eight congressional seats underscores this. Research by the Brookings Institution suggests that had the demographic trends of the migration boom years continued, Minnesota would likely lose a seat in Congress. However, with migration slowing, the question of whether the state will lose the seat is now in doubt. If Minnesota does hang on to the seat, it will be in no small part due to the state's continued natural increase. Some 97 percent of Minnesota's population growth last year was from natural increase. Utah just missed getting the 435th seat in Congress in 2000 by a few hundred people, and 74 percent of the state's growth came from natural increase last yeareven though it also has a net inflow of domestic migrants. Utah's substantial natural increase comes because it has the highest ratio of births to deaths on any state. There are nearly four births for every death in Utah. The national average is only 1.7. Such sustained high natural increase, together with migration, virtually guarantees Utah will get another seat in Congress following the 2010 election.

\section{ABOUT THE AUTHOR}

Kenneth M. Johnson is a professor of sociology and a senior demographer at the University of New Hampshire's Carsey Institute(ken.johnson@unh.edu). 